
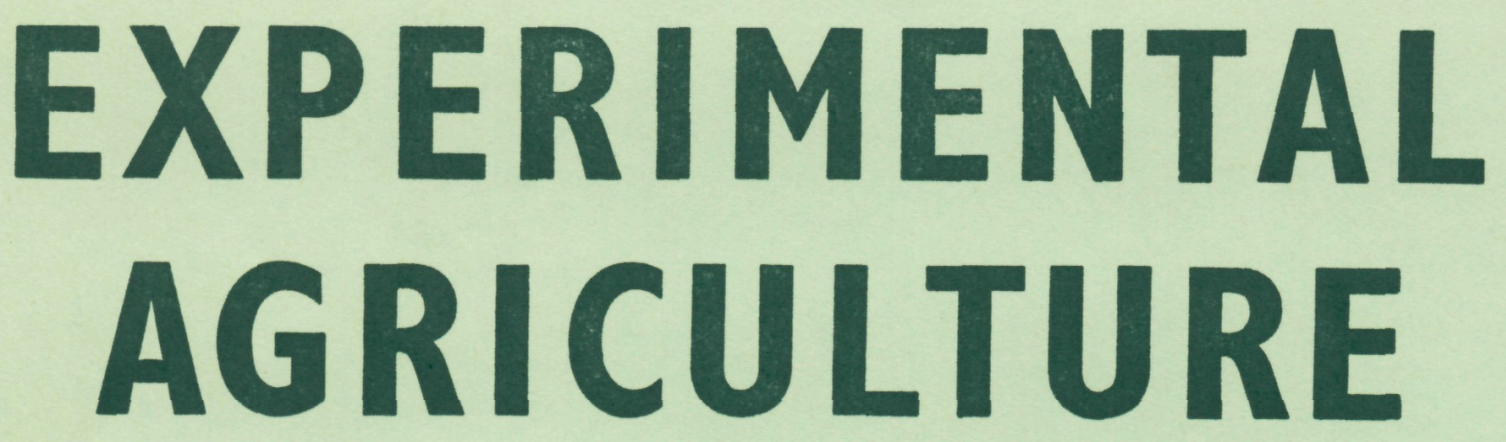

\title{
Editor
}

PROFESSOR J. P. HUDSON.

\section{Book Review Editor}

PROFESSOR N. W. SIMMONDS

\section{Editorial Board}

PROFESSOR E. W. RUSSELL (CHAIRMAN)

PROFESSOR A. H. BUNTING

PROFESSOR D. K. BRITTON

DR R. K. GUNNINGHAM

PROFESSOR J. D. IVINS
A. R. MELVILLE

PROFESSOR J. L. MONTEITH .

DR R. D. STERN

DR G. WATTS PADWICK

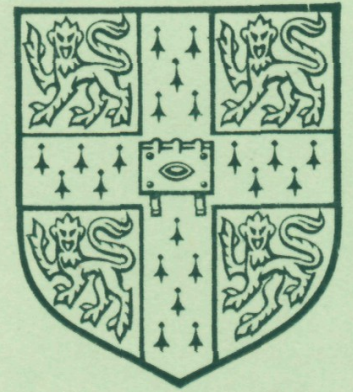

\section{CAMBRIDGE UNIVERSITY PRESS}

The Pitt Building, Trumpington Street, Cambridge, CB2 IRP

32 East 57 th Street, New York, N.Y. 10022 
Experimental Agriculture publishes the results of general agronomic work on crops, herbage and forage, with the main emphasis on field experiments relevant to husbandry in the warmer climates of the world. It also includes papers on agronomic aspects of plant breeding, and welcomes accounts of new experimental techniques, discussions of specific problems met in countries where agricultural production is developing rapidly, articles on new developments in experimental crop husbandry, and occasional papers on technical, economic and sociological aspects of farming systems. The journal is the successor to The Empire Journal of Experimental Agriculture.

Experimental Agriculture (ISSN 0014-4797) is published quarterly. Four parts form a volume.

Orders, which must be accompanied by payment, may be sent to any bookseller or subscription agent or direct to Cambridge University Press, P.O. Box i 10, Cambridge CB $2{ }_{3} \mathrm{RL}$, or in the U.S.A. and Canada, 32 East 57 th Street, New York, N.Y. I0022. The subscription price of volume 16,1980 , is $£ 28.00$ net (including postage) for a volume (US\$77.50 in the U.S.A. and Canada), payable in advance; separate parts cost $£ 8.50$ net or $\$ 25.00$ each (plus postage). Second class postage paid at New York, N.Y. POSTMASTER: send address changes in the U.S.A. and Canada to Cambridge University Press, 32 East 57th Street, New York, N.Y. I0022.

Back Volumes. Inquiries for Vols. I-32 of The Empire Fournal of Experimental Agriculture should be addressed to Wm Dawson \& Sons Ltd, Cannon House, Folkestone, Kent. Previously published parts of Experimental Agriculture are available from the Cambridge or New York offices of Cambridge University Press.

(C) Gambridge University Press 1980

Copying. This journal is registered with the Copyright Clearance Center, P.O. Box 889 I, Boston, Mass. 02114. Organizations in the U.S.A., who are also registered with C.C.C., may therefore copy material (beyond the limits permitted by sections 107 and rog of the U.S. copyright law) subject to payment to C.C.C. of the per-copy fee indicated in the code on the first page of the article. This consent does not extend to multiple copying for promotional or commercial purposes.

ISI Tear Service, 350r Market Street, Philadelphia, Pennsylvania I9ro4, U.S.A. is authorized to supply single copies of separate articles for private use only.

For all other use, permission should be sought from the Cambridge or New York offices of the Cambridge University Press.

\section{NOTES FOR GONTRIBUTORS}

Contributions will be welcomed from scientists of all nationalities, particularly those working in tropical and sub-tropical countries where up-to-date techniques of agricultural experimentation are helping in the development of more effective methods of farm production. Contributions, which must be written in English, should be sent to the Editor, Professor J. P. Hudson, The Spinney, Wrington, Bristol BSr8 7 LB, England.

Conditions of acceptance. Submission of a paper will be taken to imply that the material has not previously been published, and is not being submitted for publication elsewhere. Papers published in Experimental Agriculture may not be reprinted or published in translation without permission from the Editor, given on behalf of the Editorial Board.

General lay-out. Before having manuscripts typed contributors are asked to look carefully at the lay-out of other papers published in a recent number of this journal, to ensure that their own papers, as submitted, conform as closely as possible to the accepted pattern. This very much facilitates the work of the Editor and may often result in a paper being published earlier than if it requires a great deal of detailed editorial attention. It may also avoid the need for the paper to be referred back to the author. Numerical data can be presented in the form of tables or diagrams, but not both ways. The economics of publishing make it necessary to impose a limit on the length of papers, which should not normally exceed eight pages (including diagrams and tables) as set for printing. Tables should not be more than 80 typewriter characters wide, including spaces between words, figures and columns.

Typescripts. The top copy and one carbon copy of the script should be submitted, typed with double spacing, on one side of the paper only and with margins of about $I_{\frac{1}{2}}$ inches at the left-hand side and head of each sheet. Quarto or $\mathrm{A}_{4}$ sizes are preferred to foolscap. 